\title{
Leadership and Job Satisfaction Addressing Endogeneity With Panel Data From a Field Experiment
}

\author{
An, Seung Ho; Meier, Kenneth J.; Ladenburg, Jacob; Westergård-Nielsen, Niels
}

Document Version

Accepted author manuscript

Published in:

Review of Public Personnel Administration

DOI:

$10.1177 / 0734371 \times 19839180$

Publication date:

2020

License

Unspecified

Citation for published version (APA):

An, S. H., Meier, K. J., Ladenburg, J., \& Westergård-Nielsen, N. (2020). Leadership and Job Satisfaction:

Addressing Endogeneity With Panel Data From a Field Experiment. Review of Public Personnel Administration, 40(4), 589-612. https://doi.org/10.1177/0734371X19839180

Link to publication in CBS Research Portal

\section{General rights}

Copyright and moral rights for the publications made accessible in the public portal are retained by the authors and/or other copyright owners and it is a condition of accessing publications that users recognise and abide by the legal requirements associated with these rights.

Take down policy

If you believe that this document breaches copyright please contact us (research.lib@cbs.dk) providing details, and we will remove access to the work immediately and investigate your claim. 


\section{Leadership and Job Satisfaction: Addressing Endogeneity With Panel Data From a Field Experiment}

\section{Seung Ho An, Kenneth J. Meier, Jacob Ladenburg, and Niels Westergård-Nielsen}

Journal article (Accepted manuscript*)

\section{Please cite this article as:}

An, S. H., Meier, K. J., Ladenburg, J., \& Westergård-Nielsen, N. (2019). Leadership and Job Satisfaction: Addressing Endogeneity With Panel Data From a Field Experiment. Review of Public Personnel Administration. https://doi.org/10.1177/0734371K19839180

DOl: https://doi.org/10.1177/0734371X19839180

Copyright () The Author(s) २०19. Reprinted by permission of SAGE Publications.

* This version of the article has been accepted for publication and undergone full peer review but has not been through the copyediting, typesetting, pagination and proofreading process, which may lead to differences between this version and the publisher's final version AKA Version of Record. 


\title{
Leadership and Job Satisfaction:
}

\section{Addressing Endogeneity with Panel Data from a Field Experiment}

\author{
Seung-Ho $\mathrm{An}^{1}$ \\ Assistant Professor \\ School of Government and Public Policy \\ University of Arizona \\ seungho@protonmail.com \\ Kenneth J. Meier \\ School of Public Affairs \\ American University, \\ School of Business \\ Cardiff University, \\ and \\ the Institute of Public Administration \\ Leiden University \\ kmeier@american.edu \\ Jacob Ladenburg \\ The Rockwool Foundation \\ jla@rff.dk \\ and \\ Niels Westergård-Nielsen \\ Department of International Economics and Management \\ Copenhagen Business School \\ nwn.int@cbs.dk
}

This research was support by the Danish Council for Independent Research, project no. 132700015B

${ }^{1}$ Corresponding author. Mailing address: 315 Social Sciences Bldg, P.O.Box 210027, Tucson, Arizona, United States, 85721-0001. Phone: (520) 621-7600. Fax: (520) 621-5051 


\title{
Leadership and Job Satisfaction:
}

\section{Addressing Endogeneity with Panel Data from a Field Experiment}

\begin{abstract}
The interaction between leaders and employees plays a key role in determining organizational outcomes and performance. Although human resources management literature posits positive effects of leadership behaviors on employee job satisfaction, the causal path between the two is unclear due to potential endogeneity issues inherent in this relationship. To address the issue, we first provide theoretical explanations about why and how transformational and transactional leadership behaviors would enhance employee job satisfaction. Second, we test the relationship between leadership behaviors and employee job satisfaction using panel data from a year-long randomized field experiment that engaged leaders and employees from hundreds of public and private organizations in Denmark. Primary findings suggest that although leadership training does not have direct effects on changes in employee job satisfaction, leadership-training induced changes in leadership behaviors (transformational leadership and verbal rewards) are positively related to changes in job satisfaction.
\end{abstract}




\section{Introduction}

Except for those programs that apply incentives directly on the public, effective public programs rely on high quality human capital (Cho \& Park 2011), regardless of policy area. A key to ensure high quality human capital lies in employee satisfaction. Substantial research finds that satisfied employees are more likely to be committed to their jobs and organizations, which should, in turn, lead to higher individual and organizational productivity, and, therefore, more effective public programs (e.g. Fernandez 2008; Ostroff 1992). High levels of employee job satisfaction can also reduce the organizational costs associated with unexpected absenteeism, turnover intention, and actual turnover (Chen et al. 2011; Green 2010; Jung 2014a; Podsakoff, LePine, \& LePine 2007; Tett \& Meyer 1993).

Previous studies have suggested an extensive list of individual and organizational factors that can influence levels of employee job satisfaction, such as interpersonal relationships with colleagues and leaders, leadership, performance-based rewards, recognition, feedback, consideration from leaders, autonomy, job security, goal ambiguity, personal traits, job characteristics, co-worker wages, job changes, personal-organizational fit, organizational environments or culture, non-pecuniary job amenities and utility gaps in past and expected future jobs (for more details see Boswell, Boudreau, \& Tichy 2005; Böckerman, Ilmakunnas, \& Johansson 2011; Clark, Kristensen, \& Westergård-Nielsen 2009; Cornelissen; Heywood, \& Jirjahn 2011; Korte \& Wynne 1996; Kristensen \& Johansson 2008; Lévy-Garboua; Montmarquette \& Simonnet 2007; Muterera et al. 2015; Rainey 2003). The role of leaders can be considered as one of the most important determinants of job satisfaction not only because leaders can affect most of the aforementioned variables (except for personal traits), but also because positive interactions between leaders and employees can directly enhance job satisfaction 
(Madlock 2008, p. 65). The linkage of leadership to job satisfaction is consistent with a literature that contends that effective leadership is one of the most important characteristics commonly found in successful organizations (Bass et al. 2003).

The purpose of this article is to investigate how leadership behaviors can affect employee job satisfaction. According to the most recent meta-analysis on job satisfaction correlates by Cantarelli, Belardinelli, and Belle (2016), the relationship between leadership and job satisfaction is one of the most studied topics in public management research. ${ }^{2}$ Numerous studies find a positive relationship between leadership and job satisfaction (for more details see Cantarelli, Belardinelli, \& Belle 2016; Judge \& Piccolo 2004; Podsakoff et al. 2006). A common challenge that has often been lodged, but largely ignored in this line of research, is the failure to account for potential endogeneity issues, often using a cross-sectional data. Because the linkage between leadership and job satisfaction is so central to theories of leadership, motivation, performance, and organizations, sorting out such issues is a major theoretical challenge. To address this concern, our analysis uses panel data from a year-long randomized field experiment that engaged leaders and their followers in public and private organizations in Denmark. ${ }^{3} \mathrm{We}$ also use measures of leadership as observed by employees rather than relying on leaders' selfevaluations that are often overrated (Podakoff \& Organ 1986).

After a review of the literature on leadership and job satisfaction and a discussion concerning how leadership could affect job satisfaction, we address the potential causality and endogeneity issues on this topic. We outline theoretical expectations and hypotheses linking leadership behavior and perceptions of leadership behaviors (by leaders and employees) to

\footnotetext{
${ }^{2}$ In Cantarelli, Belardinelli, and Belle (2016)'s study, one-third of their sample studies (33 articles out of 99) deal with the relationship between leadership and job satisfaction.

${ }^{3}$ The results are identical if we limit the analysis to just the public organizations or if we drop banks, the most clearly private organization, from the analysis.
} 
employee job satisfaction. ${ }^{4}$ The study uses panel data from a large research project that experimentally induces changes in leadership and links those changes to changes in employee job satisfaction. Finally, we discuss the implications of our research for both the literature on leadership and job satisfaction, and also the practice of management.

\section{Leadership}

Although the literature on leadership is extensive and leaders can adopt myriad leadership styles, recent work has focused on the concepts of transactional and transformational leadership. Transactional leadership has roots in the early 20th century when studies on human motivation started to focus on incentives in organizations. Frederick Taylor's (1911) theory of scientific management held that well-designed incentive systems in organizations can motivate employees and enhance productivity of individuals and the organization. The focus on incentives generated a massive research literature that examined not just the monetary incentives advocated by Taylor but also the use of normative appeals, the solidary and social benefits of organizational membership, and other factors (Argyris 1972; McGregor 1960; Roethlisberger \& Dickson 1939). Leadership was to focus on creating systems of incentives that would induce organizational members to make contributions to the organization and in the process blend their personal goals with the goals of the organization (Barnard 1938; Simon 1947). Although there were many different approaches to incentives-based leadership, Burns (1978) essentially grouped them as transactional leadership whereby leaders offer verbal or material rewards (or punishments) in exchange for good (or bad) performance. Transactional leadership was to serve as the base for Burns' advocacy of transformational leadership.

\footnotetext{
${ }^{4}$ In this article, we use job satisfaction, employee satisfaction, employee job satisfaction interchangeably.
} 
Transformational leadership goes beyond the notion of economic and social exchanges (e.g. rewards or punishments) between leaders and followers (Bass et al. 2003) and focuses on inspiring, stimulating, and energizing employees to achieve challenging goals or visions beyond their capacity (Burns 1978; Bass 1985; Wright, Moynihan, \& Pandey 2012, p. 207). In seeking to tap into higher level psychological and social needs, transformational leadership tries to convince employees to adopt organizational goals as their own. In the process such leadership encourages employees to put extra effort into working toward higher-level goals within the organization (Conger \& Kanungo 1987).

Although Burns (1978) argues transformational leaders are distinct from transactional leaders, Bass (1985) claims they are not orthogonal to each other in that a leader can have both transformational and transactional leadership styles. Contemporary literature agrees with Bass's notion that the two leadership styles are not separate; in fact, transformational leadership can augment transactional leadership. Leaders, for example, can set constructive, but challenging, goals and then give certain types of rewards to employees upon the achievements of these goals (Locke 1999; Vigoda-Gadot \& Beeri 2012). Also, if leaders consistently and clearly communicate (or interact) with employees, employees would understand such goals better (Jensen, Salomonsen, \& Moynihan 2018) and may respond to rewards and incentives more. Transactional leadership behaviors such as providing rewards or setting a clear goal can be combined with transformational efforts to focus on higher objectives. In reality, transformational leadership is unlikely to be effective if it is not buttressed by some consistent application of incentives by leaders (or in other words, transformational leadership requires a base level of transactional leadership to be effective). The following section provides more detailed explanations of this relationship between leadership and job satisfaction. 


\section{Leadership and Job Satisfaction}

Regardless of leaders being transactional, transformational, or both, their key task is to develop a shared vision and overarching goals for their organizations (Bennis \& Nanus 1985; Locke \& Latham 1990) and to motivate followers to achieve those visions and goals. In doing so, transactional and/or transformational leaders are likely to enhance employees' job satisfaction through several different mechanisms (Bass 1985; Bass et al. 2003).

Under leaders with an effective transactional style, individual employees should become more satisfied with their jobs since this type of leaders clarifies their expectations and identifies the rewards for individual performance considerations (Podsakoff et al. 2006). Path-goal theory articulates this well; persons with authority in organizations should deal with organizational and environmental uncertainty by offering clarification about ambiguous goals and tasks, thereby allowing subordinates to clearly understand the roles required to achieve shared goals (House 1996). Through the transactional leader's explicit instructions about the path to organizational goals, employees may get intrinsic satisfaction and also be advised about how to obtain extrinsic rewards (House 1996; Kim, Egan, \& Moon 2014, pp. 239-240). When employees are rewarded (that is, leaders consistently reward the behavior that they are seeking), they will be recognized by others and feel more valued, which should enhance job satisfaction (Pillai, Schriesheim, \& Williams 1999). Although monetary rewards are not frequently available in public organizations, public managers can still use verbal and/or other rewards to motivate employees. Even in public organizations, however, leaders can offer material incentives such as opportunities for training, improved physical environments, or more liberal interpretation of leave requirements. In short, with transactional leaders' provision of the connection between work effort and goal 
accomplishment, as well as between goal attainment and rewards (House 1996, p. 326), employees are more likely to be more satisfied with their jobs.

Transformational leadership also plays an important role in promoting employee job satisfaction because transformational leaders encourage their followers to achieve higher levels of human needs. Given that public sector employees are more likely to be intrinsically motivated, transformational leadership plays a key role in improving employee job satisfaction in public organizations (Orazi, Turrini, \& Valotti, 2013). Burns (1978) developed the idea of transformational leadership based on Maslow's theory of a hierarchy of needs where esteem and self-actualization constitute the two highest needs of humans (Herzberg 1966; Maslow 1943). This theory is directly applied to the perspectives on leadership and employee job satisfaction; because the job can now lead to employees attaining their own higher order needs, successful transformational leadership can improve job satisfaction as it improves organizational performance. Specifically, key elements of transformational leadership - (1) developing a clear vision, (2) emphasizing the need for working together to accomplish the vision, (3) communicating with employees to share and accept the common vision, and (4) assisting employees' efforts to achieve (Paarlberg \& Lavigna 2010; Wright, Moynihan, \& Pandey 2012; Wright \& Pandey 2010) - can theoretically contribute to an employee's achievement of esteem and self-actualization needs.

First, leaders who exercise transformational skills tend to set challenging goals, thereby providing their employees with inspirational motivation to achieve these objectives. When employees succeed in attaining challenging tasks, they are more likely to fulfill higher levels of human needs (Judge et al. 2005; Jung 2014b). Second, leaders with transformational traits seek to gather followers' ideas as an effort to move forward and develop their organizations. In doing 
so, they stimulate employees to offer new perspectives to the organizations, which in turn helps the employees accomplish esteem and self-actualization needs (Judge \& Piccolo 2004). Third, transformational leaders pay attention to individual employee's concerns and needs and incorporate those in setting organizational goals, which can motivate their followers to achieve the shared organizational goals and visions (Bass 1997; Bass et al. 2003). When the employees feel that their voices are heard, their chances of fulfilling higher types of human needs are greater (e.g. Kim 2002). In all aforementioned scenarios, employees are more likely to achieve higher levels of human needs, which in turn allow them to achieve higher satisfaction with their jobs in organizations.

Although the literature linking leadership to job satisfaction is extensive, virtually all of the work is cross-sectional and correlational. ${ }^{5}$ The logic behind the studies is that leadership behavior is perceived by employees, and then employees react to the leadership style and adjust their levels of job satisfaction. It is possible that job satisfaction is not strictly endogenous to leadership, especially given that the causal linkage goes through employee perceptions of leadership. An employee with a high level of job satisfaction might allow that satisfaction to color his or her assessment of the leader and rate that leader more favorably. Sorting out these two causal paths is not possible with nonexperimental cross-sectional data.

Using panel data from a year-long experiment on leadership training, the current study seeks to address at least some of the endogeneity issues in three ways. First, we use a differencein-differences design to link changes in leadership to changes in job satisfaction. Second, incorporating the randomized experiment as an instrumental variable for changes in leadership

\footnotetext{
${ }^{5}$ Obserfield (2014) and Seidle, Fernandez and Perry (2016) are exceptions given that the former examines the relationship between leadership behaviors and work attitudes using longitudinal data and the latter employs experimental methods to assess the linkage between general leadership training and job performance.
} 
within this difference-in-differences design provides a strong causal test for the relationship between leadership and job satisfaction. Third, based on the panel analysis results, a pseudo error correction model is examined to illustrate that job satisfaction responds to both initial levels of leadership and to changes in leadership. Finally, a set of robustness checks is incorporated to assess the validity of the findings. The results are consistent with the theoretical notion that leadership is exogenous to and can influence job satisfaction.

\section{The Experiment}

Our field experiment was conducted in Denmark from March 2014 to October 2015. Invitations were sent to all leaders in the following organizations: primary and lower secondary schools in the public and private sectors, public upper secondary schools, public and private daycare centers, public tax offices and private banks. All organizations operate highly regulated programs by the government. The invitation letters stated that if leaders agree to participate in our experiment, they would have a 75 percent chance of receiving a full year of leadership training. To be eligible, leaders could not participate in any other leadership training programs during the experiment; leaders who were already participating in any types of leadership programs were excluded from our sample. A total of 672 leaders agreed to participate in the experiment; they were randomly assigned to one of the three leadership training groups (transformational, transactional, and combined (both transformational and transactional training) and a control group (no leadership training). ${ }^{6}$

Experienced leadership instructors provided the participants with leadership training four times over a year, for a total of 28 hours. The leadership training intended to develop the

\footnotetext{
${ }^{6}$ Although we did not provide any leadership training to the control group, to minimize attrition, we promised the leaders in the control group that we will provide special access to future training programs and a leadership evaluation report (after the experiment).
} 
participants' managerial capacity, which provides them with knowledge and reflections on the best leadership practices, as well as helps them implement effective leadership behaviors (Holten, Bøllingtoft, \& Wilms, 2015; Jensen et. al., 2016). To increase accessibility and participation, leadership training courses were offered in seven different locations in Denmark; participants attended in the training sessions held at the nearest location, where they had the same instructor for all four sessions. As a part of leadership training, the instructors covered 600 pages of curricula, conducted various class activities, and provided feedback on the participants' leadership skills. Coursework was also assigned to leaders between the class sessions. Across treatment groups, the structure and schedule of leadership training are the same except for the contents; transformational, transactional, and combined leadership training focuses on vision, creating incentives, or both, respectively. The leadership training curriculum in our experiment is equivalent to an executive master level course in Danish education. ${ }^{7}$

Among 672 leaders, 506 leaders completed the year-long leadership training. Before and after leadership training, we asked a set of survey questions regarding job satisfaction as well as leadership behaviors to both leaders as well as all employees in the organizations. ${ }^{8} \mathrm{~A}$ total of 452 leaders and 4,017 employees completed (or at least partially completed) both pre- and postsurveys. Since our study concerns changes in behaviors, we only include employees and leaders who complete both surveys. Figure 1 depicts the number of leaders who agreed and participated in the leadership training program.

[Figure 1 about here]

\footnotetext{
${ }^{7}$ An outline of our teaching and learning principles and course plans for each treatment are provided in Appendix A in Jensen, Moynihan, and Salomonsen (2018). The detailed teaching manual as well as summaries of key findings of other studies using this data can also be found in the project website: http://ps.au.dk/en/research/researchprojects/leap-leadership-and-performance/.

${ }^{8}$ Among 506 leaders, we sent out surveys to 477 leaders who have responsibilities in managing employees. A total of 452 leaders completed or at least partially completed to our survey questions. All employees in the organizations are surveyed via email provided by the leaders participating our leadership program.
} 
We must limit our analysis to survey responses from 439 leaders in public and private organizations (transformational=102; transactional=105; combined=110; and control $=122$ ) and their 3,940 employees (transformational=981; transactional=993; combined=999; and control=967) due to missing information from the survey. Post-experiment checks were made to determine 1) whether our randomization worked and 2) whether there were significant differences among locations or individual instructors. No such differences across groups are found from the set of tests (balance test results available upon request). We, however, still include a set of control variables to improve the precision of estimates.

\section{Analytical Approach}

We use a variety of statistical methods to take advantage of both the experimental design and the panel nature of the data. The analysis starts with a difference-in-differences design to test how changes in leadership behaviors affect changes in employee job satisfaction before and after our leadership training. Within this design, we then use participation in an experimental group as an instrument for changes in leadership. We then probe the long and short term linkages between leadership and job satisfaction by showing that job satisfaction responds to both the existing level of leadership and changes in leadership. Two additional threats to our findings - common source bias and selection bias - are examined, but do not affect the basic results. Because there are both individual and organizational level variables, we use clustered standard errors at the organizational level since the failure to account for the multilevel data structures can bias standard errors downward.

\section{Measures}

\section{Job Satisfaction}

Many diverse definitions of job satisfaction have been adopted by different scholars based on 
different research designs and contexts (Locke 1969; Rainey 2003). We adopt Kalleberg's (1977, p. 126) definition of job satisfaction; "job satisfaction is an overall affective orientation on the part of individuals toward work roles which they are presently occupying." Using this definition we directly asked the subjects: "All in all on a scale from 0 to 10 , how satisfied are you with your current job?" by doing so, we could calculate the changes in employee job satisfaction before and after the leaders were trained. Higher values on the scale indicate employees are more satisfied with their jobs. Previous studies validate the use of a single survey item on job satisfaction (see Nagy 2002; Oshagbemi 1999; Wanous, Reichers, \& Hudy 1997); in those studies, the correlations between a single survey item job satisfaction measure and multiple item measures are fairly high. The single survey item on job satisfaction has been, therefore, widely used in social science studies (e.g. Lee \& Kim 2017, Caillier 2012, 2013; West \& Berman, 2009; Kiefer et al. 2014; Whitford \& Lee 2014). Using both pre and post employee surveys, we calculate the changes in employee job satisfaction.

\section{Leadership}

Our key independent variables of interest are leadership behaviors — the use of transformational leadership, verbal rewards, and material rewards — perceived by employees and leaders. We distinguish between leaders' self-assessments of behavior and employee's assessments of leadership for two reasons. First, leaders are likely to overestimate their own leadership behaviors, reflecting a general bias where by individuals tend to over rate themselves on desirable traits (Kruger 1999). Second, for changes in leadership behaviors to affect job satisfaction, employees need to perceive that leadership has actually changed. If the changes in leaders' behavior are too subtle to be observed, they are unlikely to affect employees' job satisfaction. We use 5-point Likert scale (1=strongly disagree; and 5 strongly agree) survey items 
to measure the leadership behaviors. Both leaders and employees responded to a series of questions about supervisors' leadership before and after the experimental training. We use a series of leadership scales Jensen et al. (2016) have demonstrated to have both strong convergent and discriminant validity for both public and private sector organizations.

Transformational leadership was measured with four survey items. Respondents were asked whether leaders 1) clarify organizational visions, 2) stress the need for employees to work together to achieve the visions, 3) work on having employees to accept common organizational goals, and 4) help employees contribute to the achievement of the organizational goals. All the four questions are loaded in one factor, respectively for employees and leaders, with correlations between 0.846 and 0.898 and a Cronbach's alpha of 0.894 (for employees) and correlations between 0.673 and 0.828 and a Cronbach's alpha of 0.738 (for leaders).

The measure for the use of verbal rewards was composed of three survey items that capture whether leaders 1) provide employees with positive feedback when they perform well, 2) show their appreciation of employees when they accomplish more than expected, and 3) give compliments to employees for their outstanding works. The three items for both leaders and employees positively loaded on one single factor. Factor loadings are between 0.929 and 0.95 with a Cronbach's alpha of 0.935 (for employees), and between 0.845 and 0.87 with a Cronbach's alpha of 0.821 (for leaders).

Three survey items measure the use of material rewards. The items ask respondents whether leaders 1) clarify what rewards employees will receive when they meet the requirements, 2) reward employees when they meet the performance requirement, and 3) give rewards depending on the employees' performance. The three items loaded onto a single factor with correlations between 0.852 and 0.921 with a Cronbach's alpha of 0.876 (for employees) and 
correlations between 0.768 and 0.879 with a Cronbach's alpha of 0.78 (for leaders). ${ }^{9}$

We use an additive measure of the survey items for each leadership behavior, adjusting the measure so that it ranges between 0 and 100 (to allow comparisons across the scales that contain a different number of items), and then calculating the difference of each leadership behavior before and after the leadership training, which can theoretically range between -100 and +100 . The summary statistics of all variables used in our analyses and factor loadings are presented in the Appendix.

\section{Findings}

Quality leadership, whether transformational or transactional, should specify clear goals, communicate expectations to employees, provide feedback on that performance, and contribute either extrinsic or intrinsic rewards to the employees. Such leadership quite logically then should affect the employee's job satisfaction. By providing leadership training, organizations seek to change leadership styles and, in turn, reap the downstream benefits of improved performance via increased job satisfaction (and associated motivation) with subsequent benefits for the organization. Model 1 in Table 1 shows the effects of transformational, transactional, and combined leadership training on changes in employee job satisfaction. The results show no statistically significant relationships between the treatments and employee job satisfaction.

\section{[Table 1 About Here]}

Assignment to leadership training, however, is not necessarily the same as changing a leadership style, and one might expect that the impact of training would vary across individuals. Some individuals might not be affected by leadership training for a variety of reasons. The individual might perceive that the leadership style would not work or would not be allowed in

\footnotetext{
${ }^{9}$ The employees' measures are all more consistent and reliable than the leaders' measures, a finding supporting the notion that leaders' assessments are less objective and less reliable.
} 
their organization. The individual might reject the underlying assumptions in regard to motivation and leadership, or the individual might simply not understand the content of the training. Similar to a medical experiment involving changes in an individual's health regimen, there is substantial distance between the assignment to treatment and positive results from that treatment. Model 2 in Table 1 estimates the impact on job satisfaction of both the effect of perceived changes in leadership and any direct effect of the experimental conditions independent of changes in leadership style.

Changes in transformational and verbal reward leadership behaviors are positively associated with changes in job satisfaction at the $95 \%$ confidence level. If employees observe a positive change in how leaders provide various incentives ( $\Delta$ Transformational Leadership and $\Delta$ Verbal Rewards), they increase their level of satisfaction. Changes in transformational leadership and changes in verbal rewards both have approximately the same level of influence on changes in job satisfaction. ${ }^{10}$ The coefficients for the training per se when controlling for leadership changes are statistically indistinguishable from zero. The pattern of results suggests that if leaders are assigned to training, but do not change their leadership style, then employees will not respond with higher levels of job satisfaction.

As noted above, the absence of a direct training impact might be the equivalent of a medical trial where the patient does not actually take the prescribed medicine. Model 3 controls for absences from the training sessions ( 2 or more) as well as the preexisting levels of perceived leadership. ${ }^{11}$ Being absent from the training has a negative sign on job satisfaction, though it is

\footnotetext{
${ }^{10}$ The coefficient for changes in material rewards is significantly different statistically from the other two leadership coefficients. The coefficients for transformational leadership and the use of verbal rewards are not statistically different from each other.

${ }^{11}$ Missing a single leadership training session does not appear to have much impact whereas two or more generates the negative results.
} 
not statistically significant at the traditional significance level. Yet, more importantly, after controlling for absence, the independent impact of all the training interventions remains statistically insignificant. Initial levels of job satisfaction are also negative, as expected. The relative gains from leadership training decline when leaders have already adopted and are implementing the prescriptions of the leadership training. Even with these controls, the relative influence of changes in leadership on job satisfaction are not affected. All are positive and statistically significant. $^{12}$

Table 2 probes the findings for robustness and generalizability. Model 1 shows that the results are not influenced by sector; the coefficient for public sector organizations is not statistically significant and controlling for public organizations has no impact on the relationships found in Table 1. Similarly, Model 2 controls for the industry of the leaders with dummy variables for daycare centers and financial organizations (the excluded category is schools). Again the industry variables are not statistically significant, and the existing relationships are not affected by including these controls.

[Table 2 About Here]

The analysis thus far has relied on employee perceptions of leadership and ignored leaders' self-perceptions of leadership. We do so for strong methodological reasons. A large literature finds that leaders overrate their own leadership style, a specific case of a general phenomenon that individuals tend to overrate themselves in regard to positive characteristics (see

\footnotetext{
${ }^{12}$ In Model 3, the effects of leadership behaviors perceived by employees are in the range of 0.002 and 0.01 . Though the estimated effects seem to be small, it is important to relate the estimated parameters with scale of the variables. Recall that changes in leadership behaviors range from -100 to +100 . To illustrate, for the case of transformational leadership, one standard deviation above the mean of changes in the leadership behavior (perceived by employees) is 21.36 (see Table A1 in Appendix). The estimated effect of changes in transformational leadership behavior is $0.21(21.36 * 0.01)$. Although this is a relatively modest change, it is important to note that leadership is only one factor that affects job satisfaction and expecting huge changes in job satisfaction based on a one year change in leadership may not be realistic.
} 
Brown 2012; Fleenor et al. 2010). For this reason and consistent with much of the literature on leadership, we rely on employee assessments of leadership behaviors.

The changes in leaders' self-perceptions are only weakly related to changes in employee job satisfaction (Models 1 and 2 in Table 3). In the initial models there is a slight positive relationship for changes in transformational leadership, but when the full model controls for absences and the initial level of employee perceived leadership, the relationship disappears. So while changes in leader-perceived leadership might have some indirect influence on job satisfaction, it is changes in how the employees actually perceived what leaders are doing that matters. Such findings are consistent with the logic that either leaders misperceive their own leadership style or that what leaders think they are doing may be at odds with their behavior as perceived by their employees.

\section{[Table 3 About Here]}

Thus far, the analysis shows changes in leadership are associated with changes in job satisfaction. Although strong theoretical arguments hold that leadership determines job satisfaction, it is possible that job satisfaction might also color perceptions in leadership. The panel nature of the data, however, permit us to probe the potential causal linkage in three ways by assessing Granger causality, by using the experiment itself as an instrumental variable to limit changes in leadership to only those generated by the experiment itself, and by creating a pseudo error correction model to sort out short and long term influences of leadership on job satisfaction.

Granger causality methods essentially try to sort out causality by taking advantage of time series data. A variable $\mathrm{Y}$ is predicted by past values of $\mathrm{Y}$ and past values of $\mathrm{X}$. If past values of $\mathrm{X}$ have no ability to predict current values of $\mathrm{Y}$ statistically while controlling for past values of $\mathrm{Y}$, then one concludes that $\mathrm{X}$ does not Granger cause Y. Similar assessments are then used to 
determine if Y Granger causes X. Table 4 presents the Granger equations for the relationship between the three types of leadership behavior (transformational, verbal rewards, and material rewards) and employee job satisfaction. In all three cases, the tests indicate the relationship between perceived leadership behavior and job satisfaction is not strictly exogenous. The results are consistent with the notion of a reciprocal relationship. ${ }^{13}$

\section{[Table 4 About Here]}

Fortunately, the experimental nature of our data permits us to deal with the reciprocal causality. The random assignment of our subjects to various experimental conditions provides an exogenous instrument that is designed to influence leadership directly but not directly influence job satisfaction. In Table 5 we replicate our results in Table 1 using this instrumental variable. The instrumental variable results within a difference-in-differences design provides strong evidence of the influence of leadership behaviors on employee job satisfaction. Both transformational leadership changes and verbal rewards changes are positively related to changes in job satisfaction. The impact of changes in material rewards no longer meets the basic standards for statistical significance.

\section{[Table 5 About Here]}

The basic analysis presented thus far is a classical difference-in-difference design that relates changes in one variable to changes in another. Such an analysis probes short-term relationships and assumes that it is the change in leadership rather than the existing level of leadership that affects job satisfaction. From the perspective of the employee, such a myopic view might not be fully rational. Changes in leadership, after all, might be ephemeral. One might

\footnotetext{
${ }^{13}$ Patterns such as those found here could still exist if leadership were strictly exogenous to job satisfaction if the time length for the causal influence was less than the time between the measurements. That is, if the influence of leadership behavior on job satisfaction occurs faster than one year, then the Granger equations would not be able to distinguish which variable "caused" the other.
} 
even expect that positive changes in leadership might be framed in terms of past leadership. If the quality of leadership has been high and there are positive changes, this should be a stronger signal to the employee than if the original level of leadership was poor and there were positive changes. In the latter case, the employee might hold back changes in job satisfaction until he or she could determine if the leadership changes were permanent.

This short versus long-term response to changes in leadership behavior can be modeled via a pseudo error correction approach by including both changes in the leadership variables and levels in the leadership variables (at time 1, that is before the training) in the same equation predicting changes in job satisfaction. Table 6 presents this model. For both transformational leadership and for the use of verbal rewards, the results show that changes in job satisfaction respond to both initial levels of leadership and changes in these levels of leadership. This evidence is consistent with the idea that assessments of job satisfaction are not myopic and take into consideration prior leadership patterns as well as changes in leadership. For material rewards neither changes in leadership behavior or the original level of leadership behavior appear to matter. The negative relationship with job satisfaction at time 1 again indicates the declining marginal returns in that high levels of job satisfaction are more difficult to improve than low levels.

Lastly, we run a robustness check concerning the changes in the sample from before the experiment to after the experiment. ${ }^{14}$ Some individuals did not fill out the second survey, and in some cases these individuals were no longer employed by the organization. It could well be the

\footnotetext{
${ }^{14}$ Since this study relies on employees to assess the managers' leadership behaviors and to rate their own job satisfaction, common source bias can be a potential problem as well. Although a marker variable technique has been often criticized (Podsakoff et al., 2003; Podsakoff, Mackenzie, and Podsakoff, 2012), we test the relationship using the most aggressive technique (including a first factor of all items as an independent control variable). With the marker variable, the results still remain the same (results available upon request).
} 
case that individuals who left the organization had lower levels of job satisfaction than those who remained (although the differencing adjusts for differences in levels). To determine if this might be a problem, we ran a Heckman selection bias correction model that predicted in the first stage whether or not the employee would remain in the study. The second stage of this model showed some modest selection bias, but the basic findings linking leadership and job satisfaction remained (see Table 7); in fact, with correction for selection bias, changes in material rewards now is positive and statistically significant.

[Table 7 About here]

\section{Discussion and Conclusion}

Employees with high levels of job satisfaction should bring about positive outcomes for themselves, as well as for the entire organization; they are more likely to become committed to their jobs and increase both individual-level productivity and organizational-level performance. Higher employee job satisfaction can also likely decrease employee turnover, thereby preventing the organization from facing unnecessary costs associated with the loss of human and financial resources. In addition, employee job satisfaction should be considered as important with regard to employee well-being, even if job satisfaction itself is not correlated with positive individual and/or organizational outcomes. All of these factors should contribute to successful public programs. Among other things, leadership has long been studied as one of the most important factors that affects employee job satisfaction. This study investigates the relationship between exogenously-induced changes in leadership behaviors and employee job satisfaction using data collected from a field experiment in Denmark. We provide rigorous empirical evidence how changes in leadership behaviors would increase employee job satisfaction. 
Specifically, we test whether and how the use of transformational leadership, verbal rewards, and material rewards enhance employee job satisfaction. Our findings suggest that leaders being assigned to leadership training does not have a direct association with an increase in employee job satisfaction. Rather, what matters in improving employees' satisfaction with their jobs is their perception of changes in the leaders' behaviors. When employees perceive that their leaders use more verbal rewards or become a more transformational leader, for example, they are more likely to increase their satisfaction with their job. In this article, the estimated effects of changes in the use of verbal reward and transformational leadership behavior are approximately 0.20 evaluated at one standard deviation in the leadership behavior changes. Although this is not a massive change in job satisfaction, it is important to remember that many factors affect job satisfaction and the current estimate focuses only how an induced changed in leadership is subsequently reflected in job satisfaction.

This finding has practical implications for organizational leadership and performance, indicating the importance of and the need for managing employees' perception of leadership. No matter whether leaders exercise improved leadership behaviors after training, if employees do not think that there were improvements on the leadership skills, their job satisfaction does not increase. In other words, leadership training has an indirect impact on employee job satisfaction, which can be channeled through the employee's perception of leadership behaviors. We would contend organizational leaders need to make efforts to manage employee perceptions of their leadership behaviors. Beyond just receiving leadership training and improving leadership skills by themselves, leaders should seek constant feedback on how employees think of the current leadership strategies, thereby revising and developing their leadership skills in a way that can resonate with their employees' perception of effective leadership. 
The aforementioned findings hold consistently regardless of the sector (public and private) as well as the industry (education, daycare centers, and finance (tax office and banks) in our sample). Thus, we would argue the relationship between leadership behavior and employee job satisfaction do not much differ across sector or industry. Indeed, quality leadership (in the cases of transactional, transformational, or both types of leadership) is important in improving employee job satisfaction in any kind of organization. We, however, find no statistically significant relationship between changes in the use of material rewards and changes in employee job satisfaction (see Table 5; but see the earlier preliminary results). Although we have our theoretical expectations about how the use of material rewards is related to job satisfaction, it is possible that such leadership behavior might be related to employees' satisfaction with pay rather than their satisfaction with jobs. We also have no data on the size of the material rewards, and they might be too modest to affect job satisfaction. In this regard, future studies may want to further investigate how different degrees of material (and verbal) rewards can affect employee job satisfaction. We suggest one possibility to examine the differences: investigating sectoral differences. Given the differences in human resources management processes and in availability of monetary rewards in the two different sector (public vs. private) (An, Meier, Bøllingtoft, and Anderson 2018), such endeavor not only contributes to more nuanced understanding of the relationship between transactional leadership and employee satisfaction, but also helps distinguish differences in public and private sector leadership.

We address important potential causality and endogeneity issues that have been largely ignored in this line of research, which makes a key contribution to the knowledge base on organizational leadership. The results from the Granger causality test show the potential reciprocal relationship between employee job satisfaction and leadership behaviors. As a result, 
it is possible that much research has overestimated the influence of leadership behavior on job satisfaction. We remain confident there is a causal relationship between leadership behavior and job satisfaction because the Granger tests do not reject the hypothesis that leadership Granger causes job satisfaction. In addition, when we used instrumental variables to limit the analysis to only those leadership changes that were directly associated with leadership training so that the changes in leadership were all exogenously induced, we still found a strong relationship between leadership changes and changes in job satisfaction. While our panel data obtained from randomized field experiments help us better handle the issues of endogeneity and causality than previous studies have done, future researchers might want to further investigate this question in a lab setting or with longer time period with leadership behaviors measured more frequently. The estimates from the pseudo error correction model also suggest that the short and long-term effects of leadership behaviors clearly do not go to zero. It is both the preexisting level of leadership as well as the change in leadership that are associated with greater job satisfaction.

Human resources management theories assume that leadership can causally influence job satisfaction and then subsequently affect outcomes such as employee turnover and organizational productivity. The theory has spawned an extensive industry on leadership training with the belief that if organizations can change their leaders' behaviors, then employee job satisfaction will improve as will other organizational outcomes. The supporting evidence for this crucial theoretical assumption, however, is based primarily on cross-sectional and correlational evidence, thus, it is possible that employee job satisfaction colors the employee's view of leadership and that designed changes in leadership will have little actual impact. This experimental study dealt directly with this challenge and addressed the exogeneity issue in four ways: by focusing on changes in leadership and job satisfaction via a difference-in-differences 
design, by establishing the temporal sequence via Granger causality, by limiting the analysis only to changes in leadership behavior that were experimentally induced and by demonstrating that job satisfaction responded to both initial levels of leadership as well as changes in leadership. The results consistently provide support for the theoretical contention that changes in leadership can produce subsequent changes in job satisfaction. 


\section{References}

An, S.H., Meier, K.J., Bøllingtoft, A. and Andersen, L.B. (2018). Employee Perceived Effect of Leadership Training: Comparing Public and Private Organizations. International Public Management Journal, DOI: https://doi.org/10.1080/10967494.2018.1497739, online first.

Argyris, C. (1972). Integrating the individual and the organization. Transaction Publishers.

Barnard, C. I. (1938). Functions of the executive. Cambridge: Belknap Press of Harvard.

Bass, B. M. (1985). Leadership and performance beyond expectations. Free Press; Collier Macmillan.

Bass, B. M. (1997). Does the transactional-transformational leadership paradigm transcend organizational and national boundaries? American Psychologist, 52(2), 130-139.

Bass, B. M., Avolio, B. J., Jung, D. I., \& Berson, Y. (2003). Predicting unit performance by assessing transformational and transactional leadership. Journal of Applied Psychology, 88(2), 207.

Bennis, W., and Nanus, B. (1985). Leaders: The strategies for taking charge. New York: Harper Row.

Böckerman, P., Ilmakunnas, P., \& Johansson, E. (2011). Job security and employee well-being: Evidence from matched survey and register data. Labour Economics, 18(4), 547-554.

Boswell, W. R., Boudreau, J. W., \& Tichy, J. (2005). The relationship between employee job change and job satisfaction: the honeymoon-hangover effect. Journal of Applied Psychology, $90(5), 882$.

Brown, J. D. 2012. Understanding the better than average effect: Motives (still) matter. Personality and Social Psychology Bulletin, 38 (2): 209-219.

Burns, J. M. 1978. Leadership. New York: Harper \& Row.

Caillier, J. G. (2012). The impact of teleworking on work motivation in a US federal government agency. The American Review of Public Administration, 42(4), 461-480.

Caillier, J. G. (2013). Satisfaction with work-life benefits and organizational commitment/job involvement: Is there a connection?. Review of Public Personnel Administration, 33(4), 340-364.

Cantarelli, P., Belardinelli, P., \& Belle, N. (2016). A meta-analysis of job satisfaction correlates in the public administration literature. Review of Public Personnel Administration, 36(2), 115-144.

Chen, G., Ployhart, R. E., Thomas, H. C., Anderson, N., \& Bliese, P. D. (2011). The power of momentum: A new model of dynamic relationships between job satisfaction change and turnover intentions. Academy of Management Journal, 54(1), 159-181. 
Cho, Y. J., \& Park, H. (2011). Exploring the relationships among trust, employee satisfaction, and organizational commitment. Public Management Review, 13(4), 551-573.

Clark, A. E., Kristensen, N., \& Westergård-Nielsen, N. (2009). Job satisfaction and co-worker wages: Status or signal?. The Economic Journal, 119(536), 430-447.

Cornelissen, T., Heywood, J. S., \& Jirjahn, U. (2011). Performance pay, risk attitudes and job satisfaction. Labour Economics, 18(2), 229-239.

Conger, J. A., \& Kanungo, R. N. (1987). Toward a behavioral theory of charismatic leadership in organizational settings. Academy of Management Review, 12(4), 637-647.

Favero, N., \& Bullock, J. B. (2014). How (not) to solve the problem: An evaluation of scholarly responses to common source bias. Journal of Public Administration Research and Theory, 25(1), 285-308.

Fernandez, S. (2008). Examining the effects of leadership behavior on employee perceptions of performance and job satisfaction. Public Performance \& Management Review, 32(2), 175-205.

Fleenor, J. W., Smither, J. W., Atwater, L. E., Braddy, P. W., \& Sturm, R. E. (2010). Selfother rating agreement in leadership: A review. The Leadership Quarterly, 21(6), 10051034.

Green, F. (2010). Well-Being, Job Satisfaction and Labour Mobility. Labour Economics 17 (6): 897-903.

Herzberg, F. I. (1966). Work and the Nature of Man.

House, R. J. (1966). Path-Goal Theory of Leadership: Lessons, Legacy, and a Reformulated Theory. The Leadership Quarterly 7 (3): 323-352.

Jensen, U.T., Andersen, L.B., Bro, L.L., Bøllingtoft, A., Eriksen, T.L.M., Holten, A.L., Jacobsen, C.B., Ladenburg, J., Nielsen, P.A., Salomonsen, H.H. \& Westergård-Nielsen, N., (2016). Conceptualizing and measuring transformational and transactional leadership. Administration \& Society, online first (DOI10.1177/0095399716667157).

Jensen, U.T., Moynihan, D.P. \& Salomonsen, H.H., 2018. Communicating the Vision: How Face- to- Face Dialogue Facilitates Transformational Leadership. Public Administration Review, 78(3), 350-361.

Judge, T. A., Bono, J. E., Erez, A., \& Locke, E. A. (2005). Core self-evaluations and job and life satisfaction: the role of self-concordance and goal attainment. Journal of Applied Psychology, 90(2), 257-268.

Judge, T. A., \& Piccolo, R. F. (2004). Transformational and transactional leadership: a metaanalytic test of their relative validity. Journal of Applied Psychology, 89(5), 755-768.

Jung, C. S. 2014a. Why are goals important in the public sector? Exploring the benefits of goal clarity for reducing turnover intention. Journal of Public Administration Research and 
Theory, 24 (1): 209-234.

Jung, C. S. 2014b. Organizational goal ambiguity and job satisfaction in the public sector. Journal of Public Administration Research and Theory, 24 (4): 955-981.

Kalleberg, A. L. (1977). Work values and job rewards: A theory of job satisfaction. American Sociological Review, 42 (1), 124-143.

Kiefer, T., Hartley, J., Conway, N., \& Briner, R. B. (2014). Feeling the squeeze: Public employees' experiences of cutback-and innovation-related organizational changes following a national announcement of budget reductions. Journal of Public Administration Research and Theory, 25(4), 1279-1305.

Kim, S., Egan, T. M., \& Moon, M. J. (2014). Managerial coaching efficacy, work-related attitudes, and performance in public organizations: A comparative international study. Review of Public Personnel Administration, 34(3), 237-262.

Kim, S. (2002). Participative management and job satisfaction: Lessons for management leadership. Public Administration Review, 62 (2): 231-241.

Korte, W. B., \& Wynne, R. (1996). Telework: Penetration, Potential and Practice in Europe. John Wiley \& Sons.

Kristensen, N., \& Johansson, E. (2008). New evidence on cross-country differences in job satisfaction using anchoring vignettes. Labour Economics, 15(1), 96-117.

Kruger, J. (1999). Lake Wobegon be gone! The" below-average effect" and the egocentric nature of comparative ability judgments. Journal of Personality and Social Psychology, 77(2), 221-232.

Lee, D. \& Kim, S. Y. 2017. A quasi-experimental examination of telework eligibility and participation in the US federal government. Review of Public Personnel Administration (online first).

Lévy-Garboua, L., Montmarquette, C., \& Simonnet, V. (2007). Job satisfaction and quits. Labour Economics, 14(2), 251-268.

Locke, E. A. (1969). What is Job Satisfaction? Organizational Behavior and Human Performance, 4 (4): 309-336.

Locke, E. A., \& Latham, G. P. (1990). Work motivation and satisfaction: Light at the end of the tunnel. Psychological Science, 1(4), 240-246.

Locke, E. A. 1999. The Essence of Leadership: The Four Keys to Leading Successfully. Lexington Books.

McGregor, D. 1960. The Human Side of Enterprise. New York: McGraw-Hill.

Madlock, P. E. (2008). The link between leadership style, communicator competence, and employee satisfaction. International Journal of Business Communication, 45(1), 61-78. 
Maslow, A. H. (1943). A Theory of Human Motivation. Psychological Review 50 (4): 370-396.

Meier, K. J., and O’Toole, L. J. 2013. Subjective organizational performance and measurement error: Common source bias and spurious relationships. Journal of Public Administration Research and Theory, 23 (2): 429-456.

Muterera, J., Hemsworth, D., Baregheh, A., \& Garcia-Rivera, B. R. (2015). The leaderfollower dyad: The link between leader and follower perceptions of transformational leadership and its impact on job satisfaction and organizational performance. International Public Management Journal, online first (DOI: 10.1080/10967494.2015.1106993)

Nagy, M. S. (2002). Using a single-item approach to measure facet job satisfaction. Journal of Occupational and Organizational Psychology, 75(1), 77-86.

Orazi, D. C., Turrini, A., \& Valotti, G. (2013). Public sector leadership: new perspectives for research and practice. International Review of Administrative Sciences, 79 (3): 486-504.

Oshagbemi, T. (1999). Overall job satisfaction: How good are single versus multiple-item measures? Journal of Managerial Psychology, 14 (5): 388-403.

Ostroff, C. The relationship between satisfaction, attitudes, and performance: an organizational level analysis. Journal of Applied Psychology, 77 (6): 963-974.

Paarlberg, L. E., \& Lavigna, B. (2010). Transformational leadership and public service motivation: Driving individual and organizational performance. Public Administration Review, 70(5), 710-718.

Pillai, R., Schriesheim, C. A., \& Williams, E. S. (1999). Fairness perceptions and trust as mediators for transformational and transactional leadership: A two-sample study. Journal of Management, 25(6), 897-933.

Podsakoff, P. M., Bommer, W. H., Podsakoff, N. P., \& MacKenzie, S. B. (2006).

Relationships between leader reward and punishment behavior and subordinate attitudes, perceptions, and behaviors: A meta-analytic review of existing and new research. Organizational Behavior and Human Decision Processes, 99(2), 113-142.

Podsakoff, P. M., MacKenzie, S. B., Lee, J. Y., \& Podsakoff, N. P. (2003). Common method biases in behavioral research: A critical review of the literature and recommended remedies. Journal of Applied Psychology, 88(5), 879.

Podsakoff, P. M., MacKenzie, S. B., \& Podsakoff, N. P. (2012). Sources of method bias in social science research and recommendations on how to control it. Annual Review of Psychology, 63, 539-569.

Podsakoff, N. P., LePine, J. A., \& LePine, M. A. (2007). Differential challenge stressorhindrance stressor relationships with job attitudes, turnover intentions, turnover, and withdrawal behavior: a meta-analysis. Journal of Applied Psychology, 92(2), 438.

Rainey, H. G. (2003). Understanding and Managing Public Organizations. John Wiley \& Sons. 
Roethlisberger, F. J. \& Dickson, W. J. (1939). Management and the worker. Cambridge, MA: Harvard University Press.

Seidle, B., Fernandez, S., \& Perry, J. L. (2016). Do leadership training and development make a difference in the public sector? A panel study. Public Administration Review, 76(4), 603-613.

Simon, H. A. (1947). Administrative behavior. New York: The Free Press.

Taylor, F. W. (1911). The principles of scientific management. New York Harper \& Row.

Tett, R. P., \& Meyer, J. P. (1993). Job satisfaction, organizational commitment, turnover intention, and turnover: path analyses based on meta-analytic findings. Personnel Psychology, 46(2), 259-293.

Vigoda-Gadot, E., \& Beeri, I. (2011). Change-oriented organizational citizenship behavior in public administration: The power of leadership and the cost of organizational politics. Journal of Public Administration Research and Theory, 22(3), 573-596.

Wanous, J. P., Reichers, A. E., \& Hudy, M. J. (1997). Overall job satisfaction: How good are single-item measures? Journal of Applied Psychology, 82 (2): 247-252.

West, J. P., \& Berman, E. M. (2009). Job satisfaction of public managers in special districts. Review of Public Personnel Administration, 29(4), 327-353.

Whitford, A. B., \& Lee, S. Y. (2014). Exit, voice, and loyalty with multiple exit options: Evidence from the US federal workforce. Journal of Public Administration Research and Theory, 25(2), 373-398.

Wright, B. E., Moynihan, D. P., \& Pandey, S. K. (2012). Pulling the levers: Transformational leadership, public service motivation, and mission valence. Public Administration Review, 72(2), 206-215.

Wright, B. E., \& Pandey, S. K. (2009). Transformational leadership in the public sector: Does structure matter?. Journal of Public Administration Research and Theory, 20(1), 75-89. 
Tables

Table 1: The effects of leadership training and behaviors on employee job satisfaction

\begin{tabular}{|c|c|c|c|}
\hline DV: $\Delta$ Employee Job Satisfaction & Model 1 & Model 2 & Model 3 \\
\hline \multirow[t]{2}{*}{ Transformational Leadership Training } & 0.011 & -0.054 & -0.091 \\
\hline & $(0.104)$ & $(0.095)$ & $(0.088)$ \\
\hline \multirow[t]{2}{*}{ Combined Leadership Training } & -0.055 & -0.138 & -0.019 \\
\hline & $(0.121)$ & $(0.122)$ & $(0.101)$ \\
\hline \multirow[t]{2}{*}{ Transactional Leadership Training } & -0.058 & -0.135 & -0.044 \\
\hline & $(0.095)$ & $(0.090)$ & $(0.080)$ \\
\hline \multirow[t]{2}{*}{$\Delta$ Transformational Leadership } & & $0.012 * *$ & $0.010 * *$ \\
\hline & & $(0.002)$ & $(0.002)$ \\
\hline \multirow[t]{2}{*}{$\Delta$ Verbal Rewards } & & $0.011 * *$ & $0.010 * *$ \\
\hline & & $(0.002)$ & $(0.002)$ \\
\hline \multirow[t]{2}{*}{$\Delta$ Material Rewards } & & $0.002+$ & $0.002+$ \\
\hline & & $(0.001)$ & $(0.001)$ \\
\hline \multirow[t]{2}{*}{ Job Satisfaction $t_{1}$} & & & $-0.445^{* *}$ \\
\hline & & & $(0.020)$ \\
\hline \multirow[t]{2}{*}{ High Absences ( $1=$ two or more absences) } & & & -0.160 \\
\hline & & & $(0.102)$ \\
\hline \multirow[t]{2}{*}{ Constant } & 0.061 & $0.121+$ & $3.483 * *$ \\
\hline & $(0.065)$ & $(0.062)$ & $(0.168)$ \\
\hline R-Squared & 0.0003 & 0.0486 & 0.2714 \\
\hline N (leaders) & 439 & 439 & 439 \\
\hline $\mathrm{N}$ (employees) & 3940 & 3940 & 3940 \\
\hline
\end{tabular}

Note: $+\mathrm{p}<0.10, * \mathrm{p}<0.05, * * \mathrm{p}<0.01$; robust clustered standard errors in parentheses; two-tailed test. 
Table 2: The effects of leadership training and behaviors on employee job satisfaction controlling for sector and industry

\begin{tabular}{|c|c|c|}
\hline DV: $\Delta$ Employee Job Satisfaction & Model 1 & Model 2 \\
\hline \multirow[t]{2}{*}{ Transformational Leadership Training } & -0.095 & -0.095 \\
\hline & $(0.088)$ & $(0.089)$ \\
\hline \multirow[t]{2}{*}{ Combined Leadership Training } & -0.018 & -0.021 \\
\hline & $(0.101)$ & $(0.101)$ \\
\hline \multirow[t]{2}{*}{ Transactional Leadership Training } & -0.046 & -0.044 \\
\hline & $(0.080)$ & $(0.080)$ \\
\hline \multirow[t]{2}{*}{$\Delta$ Transformational Leadership } & $0.010 * *$ & $0.010 * *$ \\
\hline & $(0.002)$ & $(0.002)$ \\
\hline \multirow[t]{2}{*}{$\Delta$ Verbal Rewards } & $0.010 * *$ & $0.010 * *$ \\
\hline & $(0.002)$ & $(0.002)$ \\
\hline \multirow[t]{2}{*}{$\Delta$ Material Rewards } & $0.002+$ & $0.002+$ \\
\hline & $(0.001)$ & $(0.001)$ \\
\hline \multirow[t]{2}{*}{ Job Satisfaction $t_{1}$} & $-0.446 * *$ & $-0.449 * *$ \\
\hline & $(0.020)$ & $(0.019)$ \\
\hline \multirow[t]{2}{*}{ High Absences ( $1=$ two or more absences) } & -0.162 & -0.168 \\
\hline & $(0.102)$ & $(0.102)$ \\
\hline \multirow{2}{*}{ Public Organization (public=1) } & -0.128 & \\
\hline & $(0.084)$ & \\
\hline \multirow{2}{*}{ Daycare $($ daycare $=1)$} & & 0.056 \\
\hline & & $(0.074)$ \\
\hline \multirow[t]{2}{*}{ Finance (tax office or bank=1) } & & -0.050 \\
\hline & & $(0.080)$ \\
\hline \multirow[t]{2}{*}{ Constant } & $3.608 * *$ & $3.508 * *$ \\
\hline & $(0.179)$ & $(0.174)$ \\
\hline R-Squared & 0.2718 & 0.2719 \\
\hline N (leaders) & 439 & 439 \\
\hline N (employees) & 3940 & 3940 \\
\hline
\end{tabular}

Note: $+\mathrm{p}<0.10, * \mathrm{p}<0.05, * * \mathrm{p}<0.01 ;$ robust clustered standard errors in parentheses; two-tailed test. 
Table 3: Do changes in leadership behaviors perceived by leaders also affect employee job satisfaction?

\begin{tabular}{|c|c|c|c|}
\hline DV: $\Delta$ Employee job satisfaction & Model 1 & Model 2 & Model 3 \\
\hline \multirow[t]{2}{*}{$\Delta$ Transformational Leadership (employees) } & $0.012 * *$ & $0.012 * *$ & $0.010 * *$ \\
\hline & $(0.002)$ & $(0.002)$ & $(0.002)$ \\
\hline \multirow[t]{2}{*}{$\Delta$ Verbal Rewards (employees) } & $0.010 * *$ & $0.010 * *$ & $0.009 * *$ \\
\hline & $(0.002)$ & $(0.002)$ & $(0.002)$ \\
\hline \multirow[t]{2}{*}{$\Delta$ Material Rewards (employees) } & $0.002+$ & $0.003+$ & $0.002+$ \\
\hline & $(0.001)$ & $(0.001)$ & $(0.001)$ \\
\hline \multirow[t]{2}{*}{$\Delta$ Transformational Leadership (leader) } & $0.006+$ & $0.006+$ & 0.004 \\
\hline & $(0.003)$ & $(0.003)$ & $(0.003)$ \\
\hline \multirow[t]{2}{*}{$\Delta$ Verbal Rewards (leader) } & -0.000 & 0.001 & 0.000 \\
\hline & $(0.003)$ & $(0.003)$ & $(0.002)$ \\
\hline \multirow[t]{2}{*}{$\Delta$ Material Rewards (leader) } & 0.000 & 0.001 & 0.002 \\
\hline & $(0.002)$ & $(0.002)$ & $(0.001)$ \\
\hline \multirow[t]{2}{*}{ Transformational Leadership Training } & & -0.091 & -0.126 \\
\hline & & $(0.098)$ & $(0.089)$ \\
\hline \multirow[t]{2}{*}{ Combined Leadership Training } & & -0.205 & -0.065 \\
\hline & & $(0.125)$ & $(0.105)$ \\
\hline \multirow[t]{2}{*}{ Transactional Leadership Training } & & $-0.225^{*}$ & -0.113 \\
\hline & & $(0.092)$ & $(0.081)$ \\
\hline \multirow[t]{2}{*}{ Job Satisfaction $t_{1}$} & & & $-0.449 * *$ \\
\hline & & & $(0.020)$ \\
\hline \multirow[t]{2}{*}{ High Absences ( $1=$ two or more absences) } & & & $-0.179+$ \\
\hline & & & $(0.101)$ \\
\hline \multirow[t]{2}{*}{ Constant } & 0.070 & $0.206^{* *}$ & $3.566 * *$ \\
\hline & $(0.047)$ & $(0.066)$ & $(0.168)$ \\
\hline R-Squared & 0.0451 & 0.0473 & 0.2774 \\
\hline $\mathrm{N}$ (leaders) & 395 & 395 & 395 \\
\hline $\mathrm{N}$ (employees) & 3702 & 3702 & 3702 \\
\hline
\end{tabular}

Note: $+\mathrm{p}<0.10, * \mathrm{p}<0.05, * * \mathrm{p}<0.01 ;$ robust clustered standard errors in parentheses; two-tailed test. 
Table 4: Leadership and Job Satisfaction: Granger Causality Tests

\begin{tabular}{lcc} 
Relationship & t-score & p-values \\
\hline Transformational Leadership $\rightarrow$ Job Satisfaction & 5.90 & $\mathrm{P}<.001$ \\
Job Satisfaction $\rightarrow$ Transformational Leadership & 6.85 & $\mathrm{P}<.001$ \\
Verbal Rewards $\rightarrow$ Job Satisfaction & 4.24 & $\mathrm{P}<.001$ \\
Job Satisfaction $\rightarrow$ Verbal Rewards & 5.49 & $\mathrm{P}<.001$ \\
Material Rewards $\rightarrow$ Job Satisfaction & 2.90 & $\mathrm{P}<.004$ \\
Job Satisfaction $\rightarrow$ Material Rewards & 3.92 & $\mathrm{P}<.001$ \\
\hline
\end{tabular}


Table 5: The effects of leadership training and behaviors on employee job satisfaction: Instrumental Estimation

\begin{tabular}{lcc}
\hline DV: $\Delta$ Employee Job Satisfaction & Model 1 & Model 2 \\
\hline Transformational Leadership Training & 0.004 & -0.039 \\
Combined Leadership Training & $(0.096)$ & $(0.090)$ \\
& -0.082 & 0.033 \\
Transactional Leadership Training & $(0.122)$ & $(0.103)$ \\
& -0.058 & 0.020 \\
$\Delta$ Transformational Leadership & $(0.092)$ & $(0.083)$ \\
& $0.014^{* *}$ & $0.010^{* *}$ \\
$\Delta$ Verbal Rewards & $(0.003)$ & $(0.003)$ \\
& $0.013 * *$ & $0.013^{* *}$ \\
$\Delta$ Material Rewards & $(0.002)$ & $(0.002)$ \\
& 0.001 & 0.001 \\
Job Satisfaction $t_{1}$ & $(0.002)$ & $(0.002)$ \\
High Absences (1=two or more absences) & & $-0.446^{* *}$ \\
Constant & & $(0.020)$ \\
& & -0.166 \\
R-Squared & & $(0.103)$ \\
N (leaders) & & $3.439 * *$ \\
N (employees) & 0.061 & $(0.170)$ \\
\hline
\end{tabular}

Note: $+\mathrm{p}<0.10, * \mathrm{p}<0.05, * * \mathrm{p}<0.01$; robust clustered standard errors in parentheses; two-tailed test 
Table 6: The short and long term effects of leadership behaviors on employee job satisfaction

\begin{tabular}{|c|c|}
\hline DV: $\Delta$ Employee Job Satisfaction & Model 1 \\
\hline$\Delta$ Transformational Leadership & $\begin{array}{c}0.016 * * \\
(0.002)\end{array}$ \\
\hline$\Delta$ Verbal Rewards & $\begin{array}{c}0.013 * * \\
(0.002)\end{array}$ \\
\hline$\Delta$ Material Rewards & $\begin{array}{c}0.002 \\
(0.001)\end{array}$ \\
\hline Transformational Leadership $t_{1}$ & $\begin{array}{c}0.013 * * \\
(0.002)\end{array}$ \\
\hline Verbal Rewards $t_{1}$ & $\begin{array}{c}0.006 * * \\
(0.001)\end{array}$ \\
\hline Material Rewards $t_{1}$ & $\begin{array}{c}0.001 \\
(0.001)\end{array}$ \\
\hline Job Satisfaction $t_{1}$ & $\begin{array}{c}-0.515 * * \\
(0.020)\end{array}$ \\
\hline Constant & $\begin{array}{c}2.599 * * \\
(0.172)\end{array}$ \\
\hline R-Squared & 0.3021 \\
\hline $\mathrm{N}$ (leaders) & 439 \\
\hline $\mathrm{N}$ (employees) & 3940 \\
\hline
\end{tabular}

Note: $+\mathrm{p}<0.10, * \mathrm{p}<0.05, * * \mathrm{p}<0.01$; robust clustered standard errors in parentheses; two-tailed test. 
Table 7: Heckman selection model predicting changes in job satisfaction among full sample

\begin{tabular}{|c|c|c|}
\hline Regression model: $\Delta$ Employee Job Satisfaction & $\beta$ & S.E. \\
\hline$\Delta$ Transformational Leadership & $0.014 *$ & $(0.003)$ \\
\hline$\Delta$ Verbal Rewards & $0.012 *$ & $(0.003)$ \\
\hline$\Delta$ Material Rewards & $0.006^{*}$ & $(0.003)$ \\
\hline Transformational Leadership Training & -0.200 & $(0.217)$ \\
\hline Combined Leadership Training & -0.137 & $(0.217)$ \\
\hline Transactional Leadership Training & -0.351 & $(0.226)$ \\
\hline High Absences (two or more absences $=1$ ) & -0.170 & $(0.160)$ \\
\hline Job Satisfaction $t_{1}$ & $-0.573 *$ & $(0.047)$ \\
\hline Public Organization (Public=1) & -0.144 & $(0.201)$ \\
\hline Finance (Tax offices or Bank=1) & $-0.298 *$ & $(0.150)$ \\
\hline Daycare $($ Daycare $=1)$ & -0.025 & $(0.143)$ \\
\hline Constant & $8.062 *$ & $(1.081)$ \\
\hline $\mathrm{N}$ (uncensored) & 3,940 & \\
\hline \multicolumn{3}{|c|}{$\begin{array}{l}\text { Selection model: responding to both job satisfaction survey items in } t_{1} \text { and } \\
t_{2}\end{array}$} \\
\hline Job Satisfaction $t_{1}$ & $0.020 *$ & $(0.009)$ \\
\hline Transformational Leadership Training & 0.036 & $(0.045)$ \\
\hline Combined Leadership Training & 0.024 & $(0.045)$ \\
\hline Transactional Leadership Training & $0.091 *$ & $(0.046)$ \\
\hline Transformational Leadership $t_{1}$ & $0.002 *$ & $(0.001)$ \\
\hline Verbal Rewards $t_{1}$ & $0.002 *$ & $(0.001)$ \\
\hline Material Rewards $t_{1}$ & $0.003 *$ & $(0.001)$ \\
\hline Constant & $-0.234^{*}$ & $(0.074)$ \\
\hline Mill's $\lambda$ & $-5.285^{*}$ & $(1.246)$ \\
\hline $\mathrm{N}$ & 6,300 & \\
\hline Wald $\chi^{2}$ & 187.62 & \\
\hline
\end{tabular}

Note: ${ }^{*} \mathrm{p}<0.05$; robust standard error; two-tailed test. 
Figure 1. Number of leaders who agreed to participate and completed the leadership training by types of organizations.

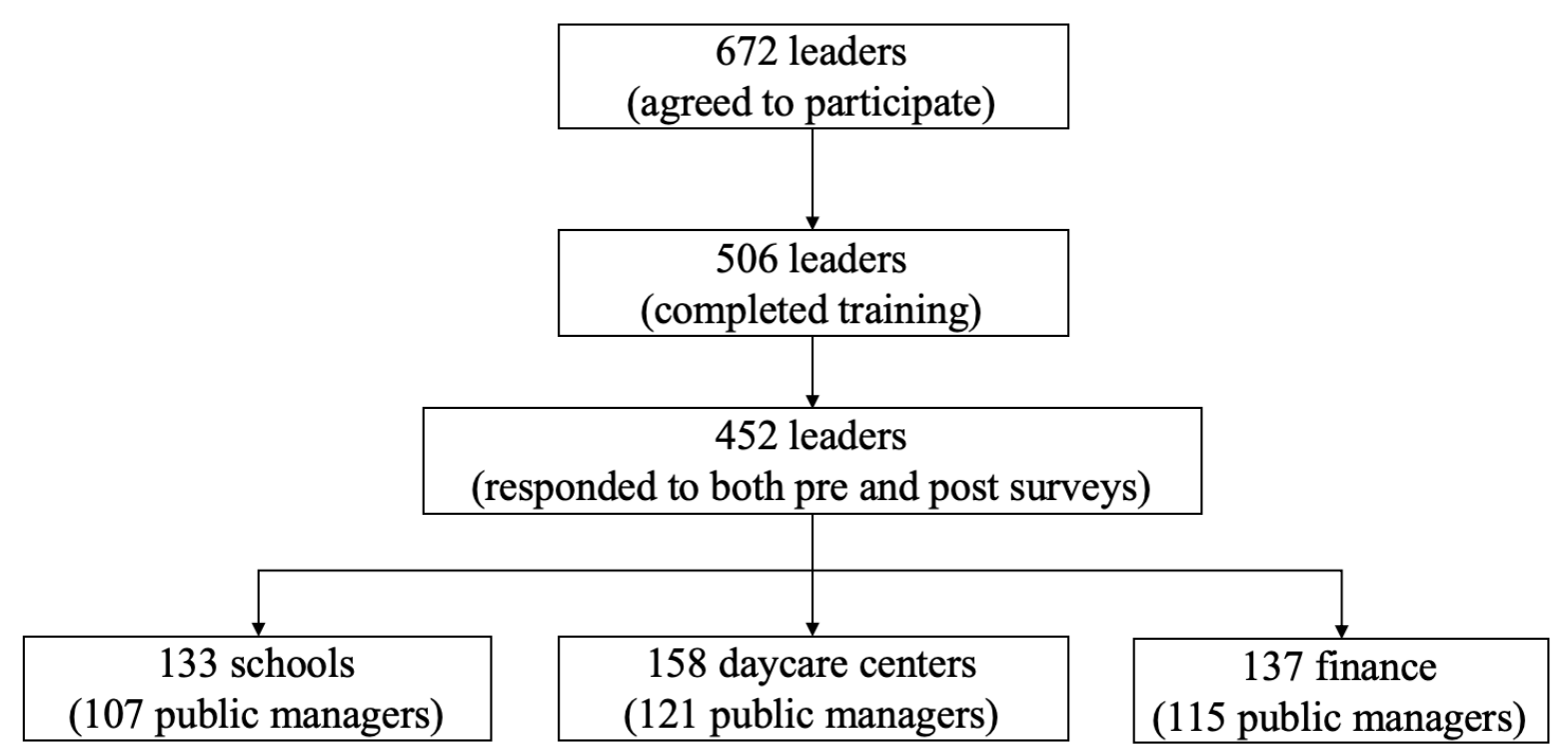


Appendix (supplemental material for publication on-line)

Table A1: Summary statistics

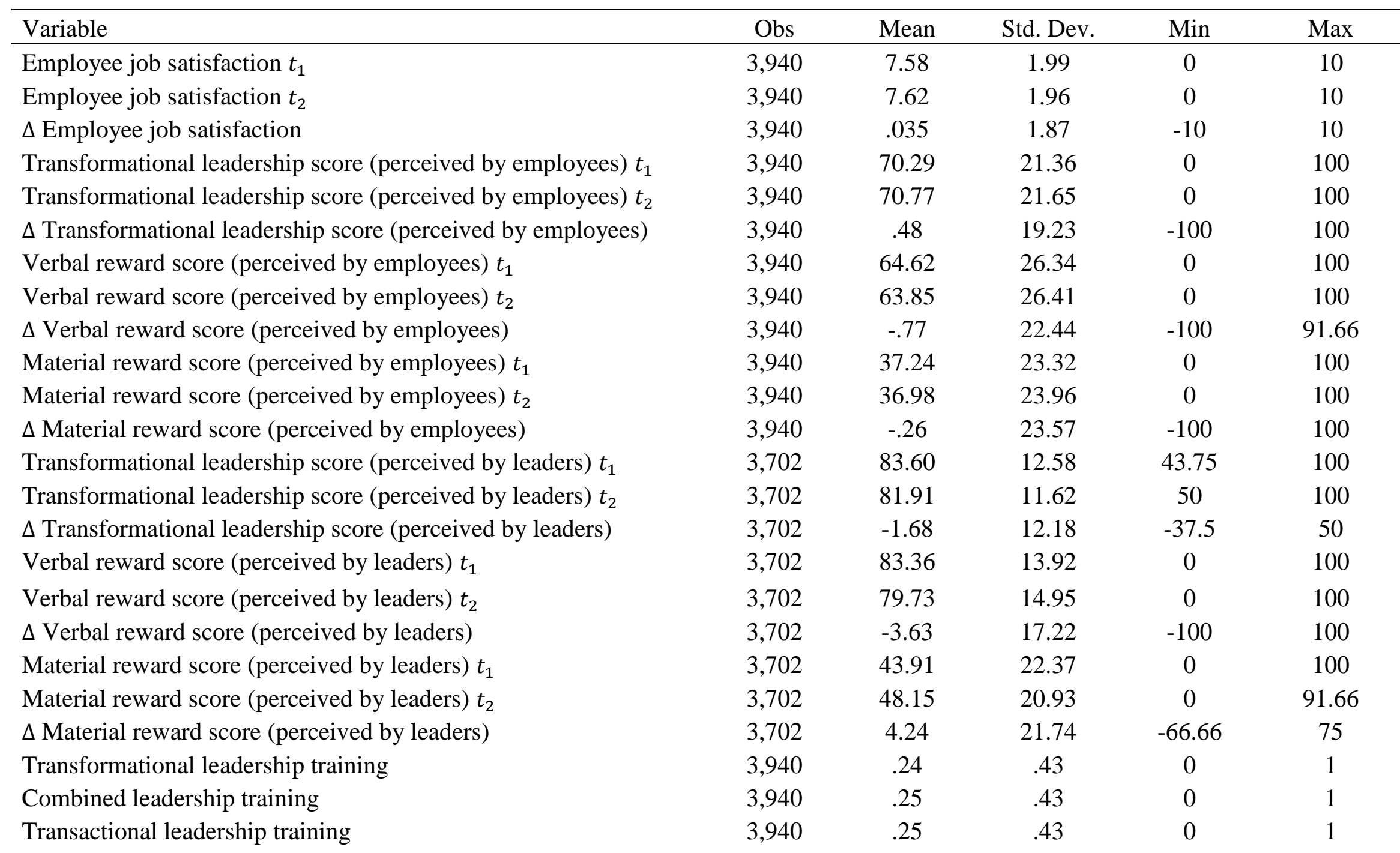


High absences ( $1=$ two or more absences)

Public Organizations (public $=1$ )

School (school=1)

Daycare $($ Daycare $=1)$

Finance (tax offices or banks=1)

$\begin{array}{ll}3,940 & .16 \\ 3,940 & .90 \\ 3,940 & .43 \\ 3,940 & .28 \\ 3,940 & .27\end{array}$

.16

.90

.43

.28

.27

\begin{tabular}{lll}
.37 & 0 & 1 \\
.29 & 0 & 1 \\
.49 & 0 & 1 \\
.45 & 0 & 1 \\
.44 & 0 & 1 \\
\hline
\end{tabular}


Table A2: Factor loadings for employee perceived leadership behavior indicators

\begin{tabular}{lc}
\hline \hline Transformational Leadership Indicators & Loading \\
\hline [leader's name] provides a concrete, clear vision for the [organization's] future & 0.862 \\
[leader's name] seeks to make employees accept common goals for the [organization] & 0.846 \\
[leader's name] strives to get the [organization's] employees to work together in the & 0.898 \\
direction of the vision & 0.883 \\
[leader's name] strives to clarify for the employees how they can contribute to & Loading \\
achieving the [organization's] goals & 0.944 \\
\hline Cronbach's alpha=0.894 & 0.925 \\
\hline \hline Verbal Rewards Indicators & 0.95 \\
\hline [leader's name] gives individual employees positive feedback when they perform well & Loading \\
\hline [leader's name] actively shows his/her appreciation of employees who do their jobs & \\
better than expected & 0.921 \\
[leader's name] personally compliments employees when they do outstanding work & 0.913 \\
\hline Cronbach's alpha=0.935 & 0.852 \\
\hline Material Rewards Indicators & \\
\hline [leader's name] rewards the employees' performance when they live up to his/her \\
requirements
\end{tabular}

Table A3: Factor loadings for leadership behavior indicators perceived by leaders

\begin{tabular}{lc}
\hline \hline Transformational Leadership Indicators & Loading \\
\hline I provide a concrete, clear vision for the [organization's] future & 0.673 \\
I seek to make employees accept common goals for the [organization] & 0.762 \\
I strive to get the [organization's] employees to work together in the direction of the & 0.827 \\
vision & 0.753 \\
\hline I strive to clarify for the employees how they can contribute to achieving the & \\
[organization's] goals & Loading \\
\hline Cronbach's alpha=0.738 & 0.87 \\
\hline \hline Verbal Rewards Indicators & 0.844 \\
\hline I give individual employees positive feedback when they perform well & 0.862 \\
I actively show his/her appreciation of employees who do their jobs better than expected & Loading \\
I personally compliment employees when they do outstanding work & 0.879 \\
\hline Cronbach's alpha=0.821 & 0.851 \\
\hline \hline Material Rewards Indicators & 0.768 \\
\hline I reward the employees' performance when they live up to his/her requirements \\
I reward the employees' dependent on how well they perform their jobs \\
I point out what employees will receive if they do what is required \\
\hline Cronbach's alpha=0.78
\end{tabular}

